\title{
Protein Kinase C Activation Increases Release of Secreted Amyloid Precursor Protein without Decreasing A $\beta$ Production in Human Primary Neuron Cultures.
}

\author{
Andréa C. LeBlanc,, ${ }^{1,3}$ Maria Koutroumanis, ${ }^{3}$ and Cynthia G. Goodyer ${ }^{2}$ \\ Departments of ${ }^{1}$ Neurology and Neurosurgery and ${ }^{2}$ Pediatrics, McGill University, Montreal, Quebec, Canada H3A 2T6, \\ and ${ }^{3}$ The Bloomfield Center for Research in Aging, Lady Davis Institute for Medical Research, The Mortimer B. Davis \\ Jewish General Hospital, Montreal, Quebec, Canada H3T 1 E2
}

Overexpression and altered metabolism of amyloid precursor protein (APP) resulting in increased $4 \mathrm{kDa}$ amyloid $\beta$ peptide $(A \beta)$ production are believed to play a major role in Alzheimer's disease (AD). Therefore, reducing $A \beta$ production in the brain is a possible therapy for AD. Because $A D$ pathology is fairly restricted to the CNS of humans, we have established human cerebral primary neuron cultures to investigate the metabolism of APP. In many cell lines and rodent primary neuron cultures, phorbol ester activation of protein kinase $C$ (PKC) increases the release of the secreted large $\mathrm{N}$-terminal fragment of amyloid precursor protein (sAPP) and decreases $A \beta$ release (Buxbaum et al., 1993; Gadzuba et al., 1993; Hung et al., 1993). In contrast, we find that PKC activation in human primary neurons increases the rate of SAPP release and the production of APP $\mathrm{C}$-terminal fragments and $4 \mathrm{kDa} A \beta$. Our results indicate species- and cell type-specific regulation of APP metabolism. Therefore, our results curtail the use of PKC activators in controlling human brain $A \beta$ levels.

Key words: amyloid precursor protein metabolism; protein kinase $C$; amyloid $\beta$ peptide; secreted amyloid precursor protein; phorbol esters; Alzheimer's disease
Overproduction of amyloid $\beta$ peptide ( $4 \mathrm{kDa} \mathrm{A} \beta$ ), either as a consequence of overexpression or increased metabolism of amyloid precursor protein (APP), is thought to play an important role in the pathogenesis of Alzheimer's disease (AD) (Selkoe, 1997). APP undergoes complex proteolytic processing. Metabolism through the secretory pathway generates the neuroprotective secreted amyloid precursor protein (sAPP) and nonamyloidogenic 3 kDa A $\beta$ secreted products (Palmert et al., 1989; Haass et al., 1993; Mattson et al., 1993). Endocytosis of cell surface APP produces internal C-terminal fragments (CTFs) of 8-12 kDa that are degraded in the lysosomes (Golde et al., 1992; Haass et al., 1992a). The $4 \mathrm{kDa} \mathrm{A} \beta$ is a minor product arising from cell surface or from Golgi-derived APP, the latter pathway being enhanced in the Swedish APP mutation (Haass et al., 1992b; Shoji et al., 1992; Busciglio et al., 1993; Koo and Squazzo, 1994; LeBlanc and Gambetti, 1994; Haass et al., 1995; Perez et al., 1996; Thinakaran et al., 1996). APP processing is cell type-specific. Human neurons secrete more $4 \mathrm{kDa}$ than $3 \mathrm{kDa} \mathrm{A} \beta$, and $\sim 40 \%$ of newly synthesized APP is metabolized through the $\alpha$-secretase pathway (LeBlanc, 1995; LeBlanc et al., 1997). In addition, human neurons produce five C-terminal fragments in a pattern uniquely observed in human brain (Estus et al., 1992; LeBlanc, 1995). In contrast, rat primary neurons, similar to most APPtransfected human or nonhuman cell lines, produce more 3 than $4 \mathrm{kDa} \mathrm{A} \beta$ and a relatively nonamyloidogenic pattern of

\footnotetext{
Received Nov. 21, 1997; revised Jan. 20, 1998; accepted Feb. 3, 1998.

This work was supported by National Institutes of Health Grant RO1 NS31700, Fond de Recherche en Santé du Québec and Alzheimer Society of Canada to A.C.L., and a Medical Research Council of Canada grant to C.G.G. We thank B. Greenberg for the anti-N antisera.

Correspondence should be addressed to Andréa LeBlanc, Lady Davis Institute for Medical Research, Sir Mortimer B. Davis Jewish General Hospital, 3755 Ch. Côte Ste-Catherine, Montréal, Québec, Canada H3T 1E2.

Copyright (C) 1998 Society for Neuroscience $0270-6474 / 98 / 182907-07 \$ 05.00 / 0$
}

C-terminal fragments (Golde et al., 1992; Haass et al., 1992a, 1993; LeBlanc et al., 1996). The neurotoxic nature of the $\mathrm{A} \beta$ has launched efforts directed at increasing APP metabolism through the $\alpha$-secretase pathway at the expense of $\mathrm{A} \beta$ production (Yankner et al., 1989, 1990; Pike et al., 1992; Forloni et al., 1993; Paradis et al., 1996).

Receptor-coupled protein kinase C (PKC)-dependent and -independent mechanisms regulate the $\alpha$-secretase pathway (Buxbaum et al., 1992; Caporaso et al., 1992; Gillespie et al., 1992; Nitsch et al., 1992; Slack et al., 1995; Xu et al., 1995). Muscarinic and metabotropic receptor-mediated activation of PKC increases the release of sAPP in $\mathrm{m} 1$ - and $\mathrm{m} 3$-transfected human embryonic kidney cells (HEK293), human umbilical vein endothelial cells, rodent primary neurons, astrocytes, and cortical brain slices (Buxbaum et al., 1992; Nitsch et al., 1992; Lee et al., 1995; Giacobini et al., 1996). In rat brain slices, acetylcholine receptor activation potentiates release of SAPP by electrical activity (Farber et al. 1995). PKC-independent tyrosine phosphorylation mediates increased release of sAPP through muscarinic receptors (Slack et al., 1993), and serotoninergic receptors regulate a PKCindependent but phospholipase A2-dependent increased release of sAPP in 3 T3 cells (Nitsch et al., 1996).

In APP-transfected HEK293, COS cells and teratocarcinoma (NT2)-derived differentiated human neuron cultures, NT2N, phorbol ester- and muscarinic receptor-mediated sAPP release diminishes A $\beta$ levels (Buxbaum et al., 1993; Gadzuba et al., 1993; Hung et al., 1993; Jacobsen et al., 1994; Wolf et al., 1995), whereas in SH-SY5Y neuroblastoma cells, A $\beta$ levels are maintained (Dyrks et al., 1994). These results suggest that the regulation of APP metabolism is also cell type-specific. To investigate PKCmediated effects in the cell type that is mainly affected in $\mathrm{AD}$, we assessed the role of PKC activation on APP metabolism in human primary neuron cultures. In the present study, we show that PKC 
activation in human primary neurons increases the rate of sAPP release without decreasing $\mathrm{A} \beta$ levels. These results indicate that amyloidogenic processing of APP cannot be dissociated from the secretory pathway by PKC activation in human primary neurons. In addition, our results indicate that the use of PKC activators is an unlikely strategy to reduce human brain $\mathrm{A} \beta$ levels.

\section{MATERIALS AND METHODS}

Cell cultures and characterization. Human primary neurons were prepared as described (LeBlanc, 1995) from human fetal brains of 13-17 weeks (Munsick, 1984). The cerebral tissues were collected as autopsy material in accordance with the Quebec Health Code and with approval of our Institutional Review Board. Briefly, the tissue, stripped of meninges and vessels, is dissociated in trypsin (Life Technologies) and deoxyribonuclease I (Boehringer Mannheim), filtered through 130 and $40 \mu$ m nylon mesh, and plated at $3 \times 10^{6}$ cells $/ \mathrm{ml}$ high glucose-containing MEM, supplemented with Earle's salts, $1 \mathrm{~mm}$ sodium pyruvate, $2 \mathrm{~mm}$ glutamine (all from Life Technologies), and 5\% decomplemented serum (Hyclone, Logan, UT). One millimolar antimitotic fluorodeoxyuridine (Sigma, St. Louis, MO) was added to inhibit proliferation of the few contaminating dividing cells. Under these conditions, neurons establish healthy neurite networks within $3 \mathrm{~d}$ and can be maintained for at least 4 weeks without showing signs of degeneration. Experiments were performed on neurons $10 \mathrm{~d}$ after plating. The neuronal cultures were characterized previously and typically contain $>90 \%$ neurons (LeBlanc, 1995).

PKC activation. PKC activation was determined with the MESACUP protein kinase assay system (Upstate Biotechnology, Lake Placid, NY). This ELISA system detects PKC-phosphorylated synthetic peptide coated to the microwell plate using a biotin-conjugated monoclonal antibody and peroxidase-conjugated streptavidin. Neuronal cell proteins were extracted in buffer A ( $25 \mathrm{mM}$ Tris, $\mathrm{pH} 7.5,2 \mathrm{mM}$ EDTA, $0.25 \mathrm{M}$ sucrose, and $50 \mathrm{~mm} \beta$-mercaptoethanol) containing $0.05 \%$ phenylmethylsulfonyl fluoride (PMSF), $0.1 \mu \mathrm{g} / \mathrm{ml}$ pepstatin A, Na-p-tosyl-L-lysine chloro-methyl ketone (TLCK), and $0.5 \mu \mathrm{g} / \mathrm{ml}$ leupeptin as protease inhibitors, and $5 \mathrm{~mm}$ EGTA, $10 \mathrm{~mm}$ sodium pyrophosphate, $1 \mathrm{~mm}$ sodium orthovanadate, and $5 \mathrm{~mm}$ sodium fluoride as phosphatase inhibitors (all protease and phosphatase inhibitors from ICN, Montreal, Quebec, Canada). The lysate equivalent of $1.5 \times 10^{5}$ cells was assayed for PKC activity as directed by the manufacturer.

Metabolic labeling and activation of PKC. To determine the effect of PKC activation on the APP secretory and endosomal-lysosomal metabolic pathways, 12 well dishes seeded with $3 \times 10^{6}$ neurons per well or $\mathrm{T}-75$ flasks containing $36 \times 10^{6}$ cells were starved in methionine- and serum-free medium for $1 \mathrm{hr}$ and labeled with EasyTag $\left[{ }^{35} \mathrm{~S}\right] \mathrm{methionine}$ (DuPont NEN, Boston, MA) for $2 \mathrm{hr}$. The radiolabel-containing media was removed and replaced for various times of chase with serum-free complete neuronal media containing one of the following: (1) $0.02 \%$ DMSO control, (2) $1 \mu \mathrm{M}$ phorbol ester dibutyrate (PDBu), (3) $1 \mu \mathrm{M}$ 12-myristate, 13-acetate phorbol dibutyrate (PMA), (4) $1 \mu \mathrm{M} \mathrm{PDBu}$ and $0.5 \mu \mathrm{M}$ okadaic acid (OKA), (5) $0.5 \mu \mathrm{M}$ OKA, (6) $1 \mu \mathrm{M}$ PDBu and $1 \mu \mathrm{M}$ staurosporin (Staur.), or (7) $1 \mu \mathrm{M}$ staurosporin. The 4- $\alpha$-phorbol-12,13didecanoate $(4 \alpha-\mathrm{P})$ was used as a nonactive homolog of PDBu. Each drug (all from Sigma) was dissolved in DMSO and added to the media in a final concentration of $0.02 \%$ DMSO. After the chase, $5 \times$ radioimmunoprecipitation assay (RIPA) buffer $(750 \mathrm{~mm} \mathrm{NaCl}, 5 \% \mathrm{NP}-40,2.5 \%$ nadeoxycholate, $0.5 \%$ SDS, $500 \mathrm{~mm}$ Tris, $\mathrm{pH} 8.0,0.05 \%$ PMSF, $0.1 \mu \mathrm{g} / \mathrm{ml}$ pepstatin A, $1 \mu \mathrm{g} / \mathrm{ml}$ TLCK, and $0.5 \mu \mathrm{g} / \mathrm{ml}$ leupeptin) was added to a final concentration of $1 \times$ RIPA buffer in the media. sAPP and A $\beta$ were immunoprecipitated with anti-N antisera (a kind gift from B. Greenberg, Cephalon), polyclonal antisera F25276, or monoclonal 4G8 (Kim et al., 1990). The cells were collected in NP-40 lysis buffer, made to $1 \times$ RIPA, and cellular APP holoprotein and CTFs were immunoprecipitated with polyclonal F25608 anti- $\mathrm{C}_{21}$ antisera as described (Lane, 1989). Anti-I (a

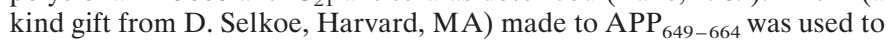
immunoprecipitate CTFs. The immunoprecipitated APP fragments were separated on a trilayer 16.5/10/4\% Tris/Tricine/SDS-polyacrylamide gel (Schagger and Von Jagow, 1987). The dried gels were exposed on Kodak (Rochester, NY) X-OMAT x-ray film or phosphorimaging for quantitation. The experiments were repeated on three independent neuron cultures.

To determine the effect of PKC activation on the steady-state levels of APP metabolic products, T-75 flasks seeded with $36 \times 10^{6}$ neurons were starved in methionine and serum-free medium for $1 \mathrm{hr}$ and then labeled for $5 \mathrm{hr}$ in the presence of each drug. The A $\beta$, sAPP, and cellular APP holoproteins were assessed by immunoprecipitation as described above. Quantitation by phosphorimaging. The quantitation of immunoprecipitated APP and APP metabolic products was done with a PhosphorImager (Molecular Dynamics, Sunnyvale, CA). Each immunoprecipitated protein or peptide was measured as volume of peak area (pixel values). Each experiment was conducted on three independent cultures. Each result within one experiment was standardized to the control DMSO-treated neuron culture, because basal levels can vary slightly in independent cultures, probably because of genetic heterogeneity of the human tissue obtained. DMSO-treated control neurons did not differ from untreated sister cultures. The final results represent the mean \pm SEM of three independent experiments. Statistical differences between two experimental groups were determined by a two-tailed unpaired $t$ test.

Determination of cell survival: MTT assay. Dimethyl-thiazoltetrazolium (MTT) reduction analysis was performed using the Cell Proliferation Kit I (Boehringer Mannheim) to determine the possible toxicity of the various drugs at the concentration indicated above. Neurons were treated for $6 \mathrm{hr}$ after preexposure to serum- and methioninefree medium for $1 \mathrm{hr}$. The conversion of the yellow tetrazolium salt MTT to blue formazan occurs in metabolically active cells. The resulting blue color is measured at absorbance of 660 and $550 \mathrm{~nm}$. MTT reduction was calculated as $A_{660}-A_{550}$, and the results are expressed as a percentage of the control DMSO sample. Decreased absorbance readings with time indicate cell death.

\section{RESULTS}

\section{Effect of PKC activation on the APP secretory pathway}

To determine whether PKC activation stimulates the release of sAPP from human neurons, cells were metabolically labeled in the presence of PMA and PDBu. Anti-N antisera immunoprecipitates two sAPPs (Fig. $1 A$ ). These two proteins also immunoprecipitated with $6 \mathrm{E} 10\left(\right.$ anti-A $\left.\beta_{1-17}\right)$ but not $4 \mathrm{G} 8$ (anti$\left.\mathrm{A} \beta_{17-24}\right)$ and are the result of $\alpha$-secretase cleavage, and the top protein likely represents a sialylated product of sAPP (Simons et al., 1996; LeBlanc et al., 1997). PMA and PDBu significantly increase the release of SAPP to 1.7 times that of control neurons (Fig. $1 B$ ). The increased sAPP release by $\mathrm{PDBu}$ is inhibited by staurosporin, a serine and threonine kinase inhibitor, whereas staurosporin alone has no effect. As expected, okadaic acid exacerbates the effect of PDBu because it maintains the phosphorylated active state of kinases. Okadaic acid alone shows a slight but statistically nonsignificant increase in sAPP. The increased metabolism of APP through the secretory pathway by $\mathrm{PMA}, \mathrm{PDBu}, \mathrm{PDBu}-$ okadaic acid, and okadaic acid is compatible with the increased release of $3 \mathrm{kDa} A \beta$ (Fig. $3 A$ ). Staurosporin inhibition of $\mathrm{PDBu}$ on sAPP release confirms that PKC-dependent serine or threonine phosphorylation events are stimulating the release of SAPP in human primary neurons as observed in other cell systems.

The potential toxicity of each drug on human primary neurons was assessed by an MTT reduction assay. The results show that cell survival was maintained in all drug-treated cultures for the duration of the experiment (Fig. 1C).

To ensure that the increased SAPP observed in phorbol ester-treated neurons is not the result of increased synthesis (Goldgaber et al., 1989), but rather of increased metabolism of APP through the $\alpha$-secretase pathway, the effect of phorbol esters on cellular APP levels and sAPP release was assessed by pulse-chase experiments. There is no change in the rate of synthesis or degradation of cellular APP with any of the drugs used (data not shown). As expected, PDBu- and PMA-treated neurons induce a threefold to fivefold statistically significant increase in sAPP release within 60-120 min of incubation compared with control untreated cells (Fig. 2A). Okadaic acid also increases sAPP release, and its addition to PDBu syner- 
A

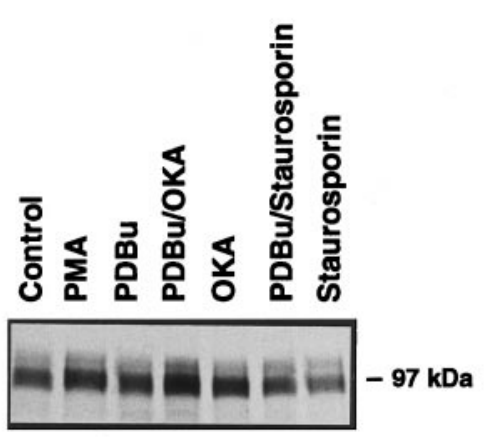

Secreted APP

B
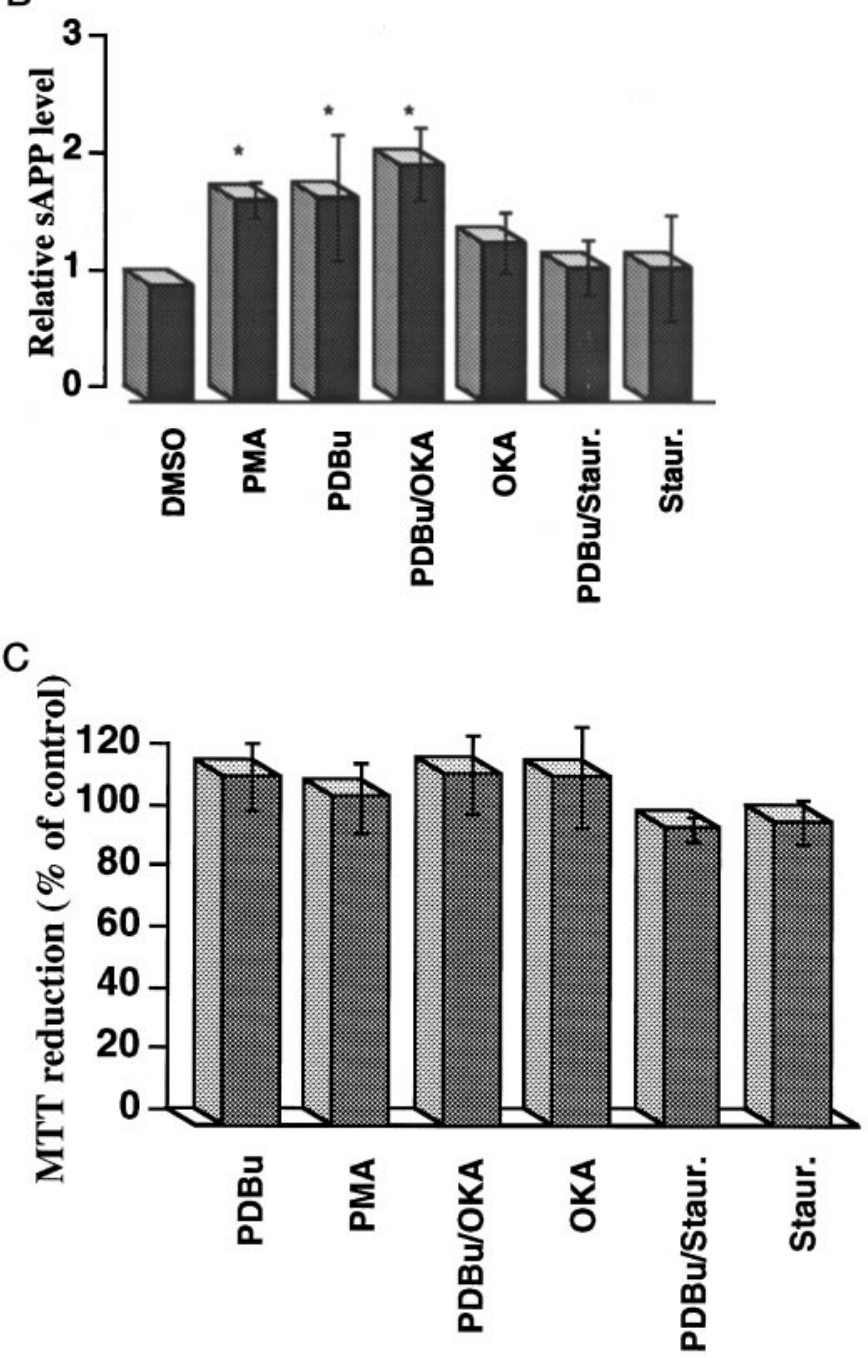

Figure 1. Release of sAPP in phorbol ester-treated neurons. The neurons were labeled for $5 \mathrm{hr}$. $A$, Autoradiogram of immunoprecipitated sAPP. B, Quantitated sAPP levels standardized to levels in DMSO-treated control neurons. PMA, PDBu, and PDBu-OKA induce a 1.7 - to 2 -fold increase in the released sAPP $\left({ }^{*} p<0.03\right)$. The results represent the mean \pm SEM of three independent cultures. $C$, Potential toxicity of each drug was tested in treated cultures by MTT reduction assay. Results are expressed as percentage of control DMSO-treated neurons and represent the mean \pm SD of three independent experiments. Staur., Staurosporin.
A

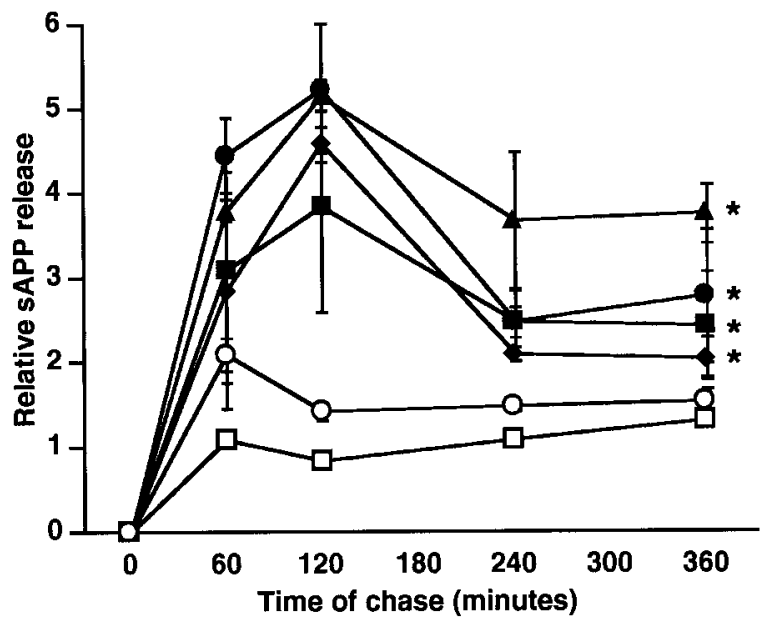

B

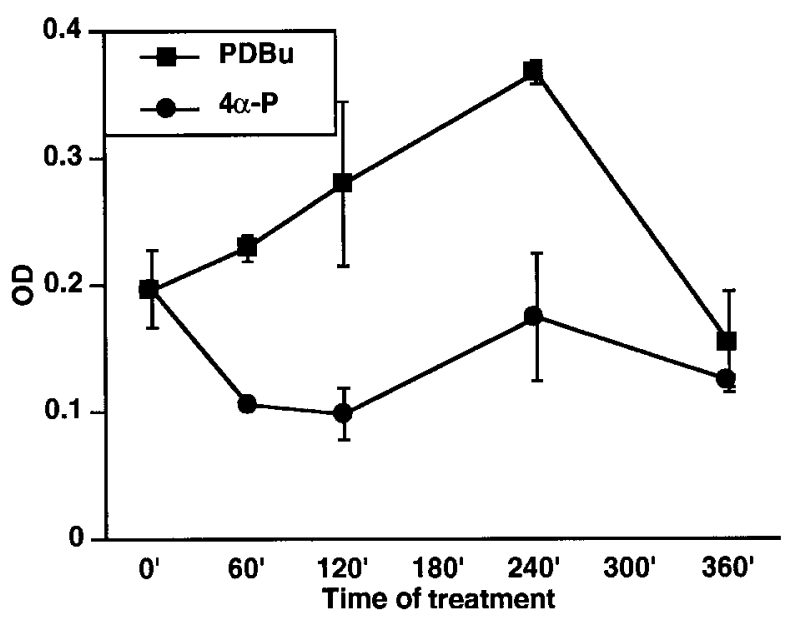

Figure 2. Increased rate of APP release and protein kinase $\mathrm{C}$ activation. Neurons were labeled for $2 \mathrm{hr}$ in the absence of drugs. $A$, The level of sAPP released during various times of chase in each of the drugs was measured by PhosphorImager, standardized to the amount of cellular APP at 0 min chase, and expressed relative to the control neurons (standardized to 1 ). *Statistically significant difference is indicated as $p<$ 0.01. $B, \mathrm{PKC}$ activation with time of exposure to PDBu or inactive analog $4 \alpha$-P. Results in $A$ and $B$ represent the mean \pm SEM of three independent cultures. Staur., Staurosporin.

gistically increases sAPP. Staurosporin shows a slight but nonsignificant increase in sAPP release at $60 \mathrm{~min}$. However, $\mathrm{PDBu}$-induced sAPP release is inhibited by staurosporin. Therefore, these results confirm that PKC activation increases the release of SAPP in human primary neurons.

The effect on sAPP release with PDBu and PMA decreased after 120 min of activation. Because autoregulation of protein kinase $\mathrm{C}$ is possible, we verified the activation of $\mathrm{PKC}$ with $\mathrm{PDBu}$ in time and found that PKC activity increases linearly up to 240 min of treatment of PDBu and returns to normal by $360 \mathrm{~min}$ (Fig. $2 B$ ). In contrast, the inactive analog of $\mathrm{PDBu}, 4 \alpha-\mathrm{P}$, did not increase PKC activity. The return to normal activity levels at 360 
min is consistent with the known autoregulation of PKC activity in many cell lines (Jaken, 1990). However, the increase in sAPP release is higher at $60-120 \mathrm{~min}$ of chase than at $240 \mathrm{~min}$ despite continued activation of PKC. Because the results are expressed relative to the SAPP released from control sister cultures, these data reflect an increased rate of SAPP release in phorbol estertreated neurons rather than an absolute increase in SAPP release.

\section{Effect of phorbol esters on the production of $4 \mathrm{kDa} A \beta$ and APP CTFs}

If PKC activation mostly increases the rate of sAPP release as opposed to the amount of APP metabolized through the secretory pathway, we would not expect any change in the level of $\mathrm{A} \beta$ produced. Our results confirm that neither PMA nor PDBu alter significantly the level of $4 \mathrm{kDa} A \beta$ released (Fig. $3 A, B$ ). However, $\mathrm{PMA}, \mathrm{PDBu}$, and okadaic acid increase the amount of $3 \mathrm{kDa} \mathrm{A} \beta$, consistent with stimulation of the secretory pathway. Staurosporin did not change the levels of $4 \mathrm{kDa} A \beta$ but did inhibit PDBu-mediated increase of $3 \mathrm{kDa} \mathrm{A} \beta$. Okadaic acid treatment results in a 1.5 -fold increase in $4 \mathrm{kDa} \mathrm{A} \beta$, but the increase does not reach statistical significance (Fig. $3 B$ ). However, increased release of $3 \mathrm{kDa} A \beta$ was observed, as expected from a stimulated secretory pathway.

To determine whether transient downregulation of $\mathrm{A} \beta$ production is masked by the later accumulation of secreted $\mathrm{A} \beta$, neurons were labeled in the absence of phorbol esters for $5 \mathrm{hr}$ and chased in the presence of PDBu for 2 and $5 \mathrm{hr}$ (Fig. 3C,D). Again, in three independent cultures, $4 \mathrm{kDa} A \beta$ immunoprecipitated from the culture media at either $2 \mathrm{hr}$, which is the time of maximal sAPP release (Figs. $2 A, 3 D$ ) or $5 \mathrm{hr}$ did not decrease. In fact, there was a 1.4 -fold increase in $4 \mathrm{kDa} \mathrm{A} \beta$ released at $2 \mathrm{hr}$ of chase that differed significantly from untreated cells $(p=0.0069)$. As expected, PDBu treatment increased the release of sAPP at both 2 and $5 \mathrm{hr}$ (Fig. 3D). The $\mathrm{PDBu}$ inactive analog $4 \alpha$-P shows a slight inhibition of sAPP and $\mathrm{A} \beta$ release at $5 \mathrm{hr}$ of treatment (Fig. $3 C$ ). The reason for this effect is not clear at this time. Intracellular $4 \mathrm{kDa} A \beta$ is not always present in human primary neurons. In the experiments in which $\mathrm{A} \beta$ was detected, there was no detectable change in the levels of $\mathrm{A} \beta$ in treated cultures (data not shown).

To determine whether increased production of $A \beta$ in the presence of $\mathrm{PDBu}$ is the result of increased APP metabolism through the endosomal pathway, we also measured the amount of CTFs produced in $\mathrm{PDBu}$-treated neurons. Human neurons produce five CTFs that are easily detected with anti- $\mathrm{C}_{21}$ and anti-I immunoprecipitations (Fig. 4A). Four of the CTFs are also immunoprecipitated with $4 \mathrm{G} 8$, showing the presence of the $\mathrm{A} \beta_{17-24}$ epitope in all except the smallest CTF. Relative to the amount of cellular full-length APP immunoprecipitated with anti- $\mathrm{C}_{21}$, and standardized to control cultures, CTFs increased twofold in the presence of PDBu (Fig. 4B). The increased production of CTFs was inhibited by staurosporin, confirming that the effect is mediated through protein kinase activation.

Therefore, based on both continuous labeling and pulsechase experiments, we conclude that in these neurons, activation of PKC accelerates the release of sAPP and increases slightly rather than decreases the production of amyloidogenic fragments.

\section{DISCUSSION}

Human neurons are long-lived cells that undergo early terminal differentiation and are expected to survive and function normally up to 10 decades of lifespan. We can therefore assume that the pathology of Alzheimer's disease that is restricted to long-lived species is intimately linked to the biology of the human neuron. An early protein kinase $\mathrm{C}$ deficit in AD has prompted the hypothesis that this signal transduction pathway may play an important role in the pathogenesis of AD (Masliah et al., 1991). Altered amyloid precursor protein metabolism is also believed to be critical in the pathogenesis of AD. The findings that receptor-mediated PKC activation increases release of sAPP indicate a close link among cholinergic receptor function, PKC activation, and APP metabolism. Although these events have been well demonstrated in many cell lines, no one has ever confirmed that these mechanisms occur in primary human neuron cultures.

Because we and others have observed higher amyloidogenic processing in human neurons relative to rodent neurons (Busciglio et al., 1993; LeBlanc, 1995; LeBlanc et al., 1997), we wondered whether the regulation of APP metabolism is also distinct in the human neurons. In the present study, we find that phorbol ester activation of PKC increases the rate of SAPP release and increases $\mathrm{A} \beta$ and APP CTF production in human primary neurons. Increased release of sAPP through PKC activation is likely the result of accelerated vesicle budding from the trans-Golgi network that redistributes APP from the trans-Golgi network toward the $\alpha$-secretase pathway, in which APP encounters its processing enzymes (Xu et al., 1995). It is known that part of cell surface APP is processed into $A \beta$ and part is produced through another pathway originating from the Golgi (Haass et al., 1992b, 1995; Shoji et al., 1992; Perez et al., 1996; Thinakaran et al., 1996). PDBu-mediated increase in $\mathrm{A} \beta$ levels suggests increased metabolism through either the endosomal or Golgi-derived pathways. The increased level of CTFs similar to increased amounts of $\mathrm{A} \beta$ supports the endosomallysosomal pathway. Increased production of CTFs by phorbol esters has been reported previously and is not unique to neurons (Buxbaum et al., 1992). The absence of reduced A $\beta$ production under conditions of stimulated SAPP release indicates that PKC activation cannot dissociate APP secretion and amyloidogenic fragment production in human primary neurons.

The increased release of sAPP in the absence of decreased $\mathrm{A} \beta$ in phorbol ester-treated human primary neurons is similar to that observed in both PMA and muscarinic receptor agonist stimulation of a subclone of the human neuroblastoma cell line SH-SY5Y (Dyrks et al., 1994) and contrasts with the results obtained in HEK293, CHO, COS, and NT2N cells in which increasing sAPP release does decrease $4 \mathrm{kDa} A \beta$ levels by as much as 50\% (Buxbaum et al., 1993; Gadzuba et al., 1993; Hung et al., 1993; Jacobsen et al., 1994; Wolf et al., 1995). The dose of phorbol ester and pulse-chase experimental conditions in these studies were comparable to ours. Therefore, the opposing results are not attributed to a dose or time response difference between human neurons and various cell lines. Similar to human primary neurons, NT2N cells express high endogenous levels of $\mathrm{APP}_{695}$ and have a relatively high amyloidogenic pattern of APP processing (Wertkin et al., 1993). However, in our human primary neuron cultures, we do not see a concomitant reduction in the production of $4 \mathrm{kDa} \mathrm{A} \beta$ with increased sAPP secretion through direct protein kinase $\mathrm{C}$ activation. The reason for the difference between primary neurons and $\mathrm{NT} 2 \mathrm{~N}$ is not clear. It is possible that the teratocarcinoma-derived neurons differ from primary neurons 
A

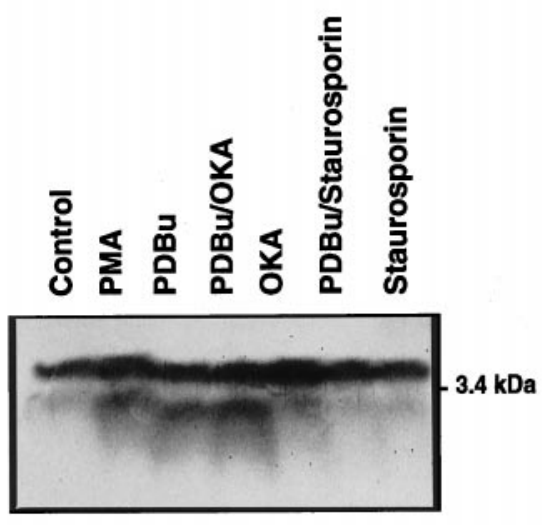

B

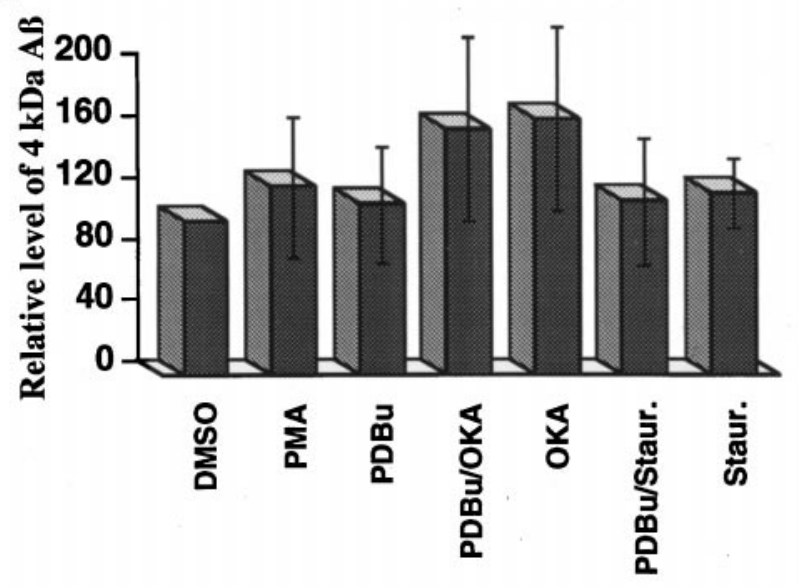

C
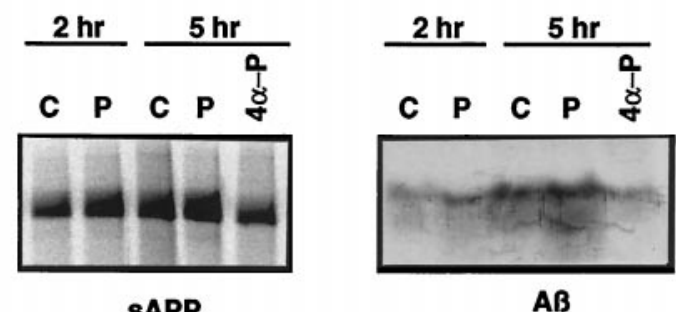

$A B$

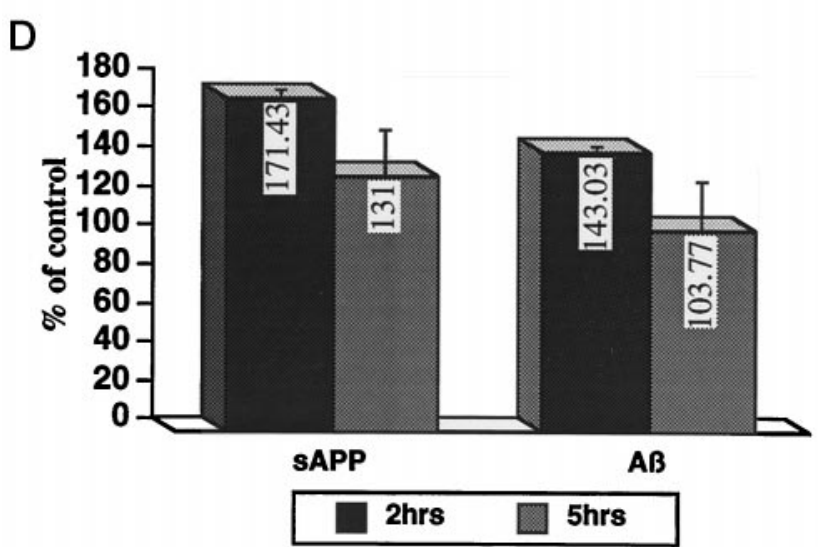

Figure 3. Effect of phorbol esters on levels of $4 \mathrm{kDa} \mathrm{A} \beta . A$, Neurons were labeled for $5 \mathrm{hr}$ in the presence of each drug. Autoradiogram of immunoprecipitated 3 and $4 \mathrm{kDa} \mathrm{A} \beta$ with $4 \mathrm{G} 8$. $B$, Quantitation of $4 \mathrm{kDa} \mathrm{A} \beta$ release shown in $A$ relative to control cultures standardized at 100. Results represent the mean \pm SD of three independent cultures. Statistically significant difference is not reached in (Figure legend continues)
A

B
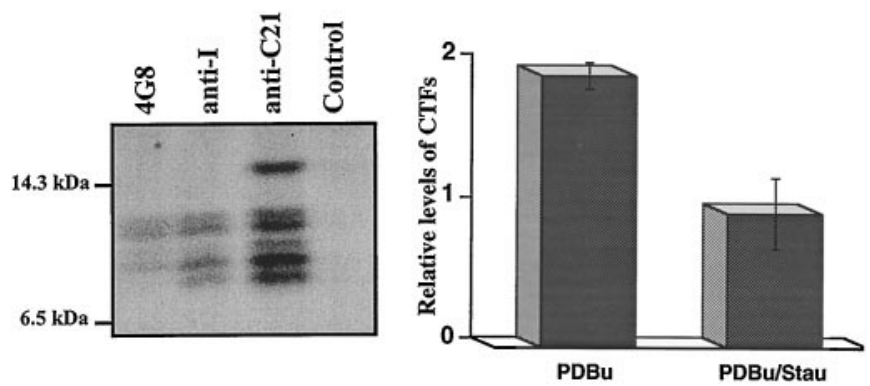

Figure 4. Effect of PDBu on APP CTFs. A, Immunoprecipitation of neuronal cellular lysates with anti- $\mathrm{C}_{21}$, anti-I, and $4 \mathrm{G} 8$ shows five APP CTFs. The higher molecular weight band was undetected by anti-I or 4G8 and cannot be derived from APP. The control lane represents an immunoprecipitation with anti- $\mathrm{C}_{21}$ competed with $\mathrm{C}_{21}$ peptide. $B$, Level of CTFs produced in PDBu- and PDBu-staurosporin (Stau)treated cells. Neurons were labeled $5 \mathrm{hr}$ with PDBu in the absence or presence of staurosporin. Results are calculated as total amount of CTFs per cellular APP holoprotein immunoprecipitated in the same sample with anti- $\mathrm{C}_{21}$ and expressed relative to control cultures. Statistical difference is reached in PDBu-treated neurons compared with controls $(p=0.0006)$. Results represent the mean $\pm \mathrm{SD}$ of three independent experiments.

with respect to protein trafficking or signal transduction. Because other systems show serotoninergic and muscarinic PKCindependent but tyrosine phosphorylation-dependent regulation of sAPP release (Slack et al., 1995; Nitsch et al., 1996), it remains to be seen whether downregulation of $4 \mathrm{kDa} \mathrm{A} \beta$ in these and our human primary neurons can be achieved through a PKC-independent pathway. The difference between the PKC-mediated APP metabolism in rodent and human primary neurons is surprising. The rodent studies suggest that in vivo, receptor-mediated $\mathrm{PKC}$ activation controls the levels of $\mathrm{A} \beta$. The absence of this regulation in human neurons may partly explain the natural accumulation of $\mathrm{A} \beta$ in aging humans.

We believe that the human primary neuron cultures are essential to the understanding of APP metabolism in human brain. Human primary neuron cultures rapidly establish a healthy and extensive neuritic network within $3 \mathrm{~d}$ of culture that is maintained for up to 3-4 weeks without any signs of neurodegeneration (LeBlanc, 1995). APP expression and metabolism in these fetal neuronal cultures closely resembles that shown in human adult brains (LeBlanc, 1995; LeBlanc et al., 1997). Therefore, it is reasonable to suggest that the regulation of APP in these human neurons closely reflects the in vivo situation in adult neurons. Our present results with the human primary fetal neurons unexpectedly show a lack of segregation of the secretory and amyloidogenic pathways of APP metabolism and argue against the use of neuronal receptor agonists or

drug-treated cells compared with controls. Staur., Staurosporin. $C$, Autoradiogram of sAPP and $\mathrm{A} \beta$ release from control $(C), \mathrm{PDBu}(P)$, or $4 \alpha$-P-treated neurons. Neurons were labeled for $5 \mathrm{hr}$ in absence of PDBu or inactive analog $4 \alpha-\mathrm{P}$ and chased 2 and $5 \mathrm{hr}$ in the presence of drugs. $D$, Quantitation of sAPP and $\mathrm{A} \beta$ release shown in $C$ expressed as the mean \pm SEM from three independent cultures. At 2 but not $5 \mathrm{hr}$, both sAPP and $\mathrm{A} \beta$ differ significantly from untreated control cells $(p=0.0062$ for $\mathrm{sAPP} ; p=0.0069$ for $\mathrm{A} \beta$ ). 
PKC activators as a mechanism to decrease levels of $\mathrm{A} \beta$ in the brain.

\section{REFERENCES}

Busciglio J, Gabuzda D, Matsudaira P, Yankner B (1993) Generation of $\beta$-amyloid in the secretory pathway in neuronal and nonneuronal cells. Proc Natl Acad Sci USA 90:2092-2096.

Buxbaum J, Ruefli A, Parker C, Cypress A, Greengard P (1993) Calcium regulates processing of the Alzheimer amyloid protein precursor in a protein kinase $\mathrm{C}$-independent manner. Proc Natl Acad Sci USA 91:4489-4493.

Buxbaum JD, Oishi M, Chen HI, Pinkas-Kramarski R, Jaffe EA, Gandy S, Greengard P (1992) Cholinergic agonists and interleukin 1 regulate processing and secretion of the Alzheimer $\beta / \mathrm{A} 4$ amyloid protein precursor. Proc Natl Acad Sci USA 89:10075-10078.

Caporaso G, Gandy S, Buxbaum J, Ramabhadran T, Greengard P (1992) Protein phosphorylation regulates secretion of Alzheimer $\beta /$ A4 amyloid precursor protein. Proc Natl Acad Sci USA 89:3055-3059.

Dyrks T, Monning U, Beyreuther K, Turner J (1994) Amyloid precursor protein secretion and $\beta / \mathrm{A} 4$ amyloid generation are not mutually exclusive. FEBS Lett 349:210-214.

Estus S, Golde T, Kunishita T, Blades D, Lowery D, Eisen M, Usiak M, Qu X, Tabira T, Greenberg B, Younkin S (1992) Potentially amyloidogenic, carboxy-terminal derivatives of the amyloid protein precursor. Science 255:726-728.

Farber SA, Nitsch RM, Schulz JG, Wurtman RJ (1995) Regulated secretion of $\beta$-amyloid precursor protein in rat brain. J Neurosci 15:7442-7451.

Forloni G, Chiesa R, Smiroldo S, Verga L, Salmona M, Tagliavini F, Angeretti N (1993) Apoptosis mediated neurotoxicity induced by chronic application of $\beta$-amyloid fragment 25-35. NeuroReport 4:523-526.

Gadzuba D, Busciglio J, Yankner BA (1993) Inhibition of $\beta$-amyloid production by activation of protein kinase C. J Neurochem 61:2326-2329.

Giacobini E, Mori F, Lai CC (1996) The effect of cholinesterase inhibitors on the secretion of APPs from rat brain cortex. Ann NY Acad Sci 777:393-398.

Gillespie SL, Golde TE, Younkin SG (1992) Secretory processing of the Alzheimer amyloid $\beta / \mathrm{A} 4$ protein precursor is increased by protein phosphorylation. Biochem Biophys Res Commun 187:1285-1290.

Golde T, Estus S, Younkin L, Selkoe D, Younkin S (1992) Processing of the amyloid protein precursor to potentially amyloidogenic derivatives. Science 255:728-730.

Goldgaber D, Harris H, HLA T, Magiag T, Donnelly R, Jacobsen J, Vitek M, Gadjusek C (1989) Interleukin 1 regulates synthesis of amyloid $\beta$-protein precursor mRNA in human endothelial cells. Proc Natl Acad Sci USA 86:7606-7610.

Haass C, Koo E, Mellon A, Hung A, Selkoe D (1992a) Targeting of cell-surface $\beta$-amyloid precursor protein to lysosomes: alternative processing into amyloid-bearing fragments. Nature 357:500-503.

Haass C, Schlossmacher M, Hung A, Vigo-Pelfrey C, Mellon A, Ostaszewski B, Lieberburg I, Koo E, Schenk D, Teplow D, Selkoe D (1992b) Amyloid $\beta$-peptide is produced by cultured cells during normal metabolism. Nature 359:322-325.

Haass C, Hung A, Schlossmacher M, Teplow D, Selkoe D (1993) $\beta$-amyloid peptide and a $3 \mathrm{kDa}$ fragment are derived by distinct cellular mechanisms. J Biol Chem 268:3021-3024.

Haass C, Lemere C, Capell A, Citron M, Seubert P, Schenk D, Lannfelt D, Selkoe D (1995) The Swedish mutation causes early-onset Alzheimer's disease by $\beta$-secretase cleavage within the secretory pathway. Nat Med 1:1291-1296.

Harlow E, Lane D (1988) Immunoprecipitations. In: Antibodies, a laboratory manual (Harlow L, ed), pp 421-466. Cold Spring Harbor, NY: Cold Spring Harbor Laboratory.

Hung AY, Haass C, Nitsch RM, Qiu WQ, Citron M, Wurtman RJ, Growdon JH, Selkoe DJ (1993) Activation of protein kinase C inhibits cellular production of the amyloid $\beta$-protein. J Biol Chem 268:22959-22962.

Jacobsen JS, Spruyt MA, Brown AM, Sahasrabhude S, Blume A, Vitek M, Muenkell H, Sonnenberg-Reines J (1994) The release of Alzhei- mer's disease $\beta$-amyloid peptide is reduced by phorbol treatment. J Biol Chem 269:8376-8382.

Jaken S (1990) Protein kinase C and tumor promoters. Curr Opin Cell Biol 2:192-197.

Kim K, Miller D, Sapienza V, Chen C, Bai C, Grundke-Iqbal I, Currie J, Wisniewski H (1990) Production and characterization of monoclonal antibodies reactive to synthetic cerebrovascular amyloid peptide. Neurosci Res Commun 2:121-130.

Koo EH, Squazzo SL (1994) Evidence that production of amyloid $\beta$-protein involves the endocytotic pathway. J Biol Chem 269: $17386-17389$

LeBlanc AC (1995) Increased production of $4 \mathrm{kDa}$ amyloid $\beta$ peptide in serum deprived human primary neuron cultures: possible involvement of apoptosis. J Neurosci 15:7837-7846.

LeBlanc AC, Gambetti P (1994) Production of Alzheimer $4 \mathrm{kDa}$ $\beta$-amyloid peptide requires the $\mathrm{C}$-terminal cytosolic domain of the amyloid precursor protein. Biochem Biophys Res Commun 204:1371-1380

LeBlanc AC, Xue R, Gambetti P (1996) APP metabolism in primary cell cultures of neurons, astrocytes and microglia. J Neurochem 66 $2300-2310$

LeBlanc AC, Papadopoulos M, Bélair C, Chu W, Crosato M, Powell J, Goodyer C (1997) Amyloid precursor protein metabolism in human neurons, astrocytes and microglia. J Neurochem 68:1183-1190.

Lee R, Wurtman R, Cox A, Nitsch R (1995) Amyloid precursor protein processing is stimulated by metabotropic glutamate receptors. Proc Natl Acad Sci USA 92:8083-8087.

Masliah E, Cole GM, Hansen L, Mallory M, Albright T, Terry R, Saitoh T (1991) Protein kinase C alteration is an early biochemical marker in Alzheimer's disease. J Neurosci 11:2759-2767.

Mattson M, Cheng B, Culwell A, Esch F, Lieberburg I, Rydel R (1993) Evidence for excitoprotective and intraneuronal calcium-regulating roles for secreted forms of the $\beta$-amyloid precursor protein. Neuron 10:243-254.

Munsick RA (1984) Human fetal extremity lengths in the interval from 9 to 21 menstrual weeks of pregnancy. Am J Obstet Gynecol 149:883-887.

Nitsch R, Slack B, Wurtman R, Growdon J (1992) Release of Alzheimer amyloid precursor derivatives stimulated by activation of muscarinic acetylcholine receptors. Science 258:304-307.

Nitsch R, Deng M, Growdon J, Wurtman R (1996) Serotonin 5-HT2a and 5-HT2c receptors stimulate amyloid precursor protein extodomain secretion. J Biol Chem 271:4188-4194.

Palmert M, Siedlak S, Podlinsny M, Greenberg B, Shelton E, Chan H, Usiak M, Selkoe D, Perry G, Younkin S (1989) Soluble derivatives of the $\beta$-amyloid protein precursor of Alzheimer's disease are labeled by antisera to the $\beta$-amyloid protein. Biochem Biophys Res Commun 165:182-188.

Paradis E, Douillard H, Koutroumanis M, Goodyer C, LeBlanc A (1996) Amyloid peptide of Alzheimer's disease downregulates Bcl-2 and upregulates Bax Expression in human neurons. J Neurosci 16:7533-7539.

Perez RG, Squazzo SL, Koo EH (1996) Enhanced release of amyloid$\beta$-protein from codon 670-671 "Swedish" mutant $\beta$-amyloid precursor protein occurs in both secretory and endocytic pathway. J Biol Chem 271:9100-9107.

Pike CJ, Cummings BJ, Cotman CW (1992) $\beta$-amyloid induces neuritic dystrophy in vitro: similarities with Alzheimer pathology. NeuroReport 3:769-772.

Schagger H, Von Jagow G (1987) Tricine-sodium dodecyl sulfatepolyacrylamide gel electrophoresis for the separation of proteins in the range from 1 to $100 \mathrm{KDa}$. Anal Biochem 166:368-379.

Selkoe D (1997) Alzheimer's Disease: genotypes, phenotype and treatments. Science 275:630.

Shoji M, Golde T, Ghiso J, Cheung T, Estus S, Shaffer L, Cai X, McKay D, Tintner R, Frangione B, Younkin S (1992) Production of the Alzheimer amyloid $\beta$ protein by normal proteolytic processing. Science 258:126-129.

Simons M, DeStrooper B, Multhaup G, Tienari PJ, Dotti CG, Beyreuther K (1996) Amyloidogenic processing of the human amyloid precursor protein in primary cultures of rat hippocampal neurons. J Neurosci 16:899-908.

Slack BE, Breu J, Petryniak M, Srivastava K, Wurtman R (1995) Ty- 
rosine phosphorylation-dependent stimulation of amyloid precursor protein secretion by the $\mathrm{m} 3$ muscarinic acetylcholine receptor. J Biol Chem 270:8337-8344.

Slack BE, Nitsch R, Livneh E, Kunz G, Breu J, Eldar H, Wurtman R (1993) Regulation by phorbol esters of amyloid precursor protein release from Swiss $3 \mathrm{~T} 3$ fibroblasts overexpressing protein kinase C-alpha. J Biol Chem 268:21097-21101.

Thinakaran G, Teplow D, Siman R, Greenberg B, Sisodia S (1996) Metabolism of the "Swedish" amyloid precursor protein variant in Neuro2A (N2a) cells. J Biol Chem 16:9390-9397.

Wertkin AM, Turner RS, Pleasure SJ, Golde TE, Younkin SG, Trojanowski JQ, Lee V (1993) Human neurons derived from a teratocarcinoma cell line express solely the 695 -amino acid amyloid precursor protein and produce intracellular $\beta$-amyloid or A4 peptides. Proc Natl Acad Sci USA 90:9513-9517.
Wolf B, Wertkin A, Jolly Y, Yasuda R, Wolfe B, Konrad R, Manning D, Ravi S, Williamson J, Lee V (1995) Muscarinic regulation of Alzheimer's disease amyloid precursor protein secretion and amyloid $\beta$-protein in human neuronal NT2N cells. J Biol Chem 270:4916-4922.

Xu H, Greengard P, Gandy S (1995) Regulated formation of Golgi secretory vesicles containing Alzheimer $\beta$-myloid precursor protein. J Biol Chem 270:23243-23245.

Yankner BA, Dawes LR, Fisher S, Villa-Komaroff L, Oster-Granite M, Neve RL (1989) Neurotoxicity of a fragment of the amyloid precursor protein associated with Alzheimer's disease. Science 245:417-420.

Yankner BA, Duffy LK, Kirschner DA (1990) Neurotrophic and neurotoxic effects of amyloid $\beta$ protein: reversal by tachykinin neuropeptides. Science 250:279-286. 